\title{
Drought-tolerant Common Bush Bean Physiological Parameters as Indicators to Identify Susceptibility
}

\author{
Alefsi David Sánchez-Reinoso, Gustavo Adolfo Ligarreto-Moreno, \\ and Hermann Restrepo-Díaz \\ Departamento de Agronomía, Universidad Nacional de Colombia, Bogotá \\ D.C., Colombia.
}

Additional index words. leaf gas exchange, lipid peroxidation, physiological breeding, proline

\begin{abstract}
Bean crops can be displaced to marginal areas or face abiotic stresses such as water deficit. Physiological responses allow the identification of tolerant genotypes and lead to more precise breeding strategies. The objective of this research was to evaluate the physiological (leaf gas exchange properties, leaf water content, and leaf thickness) and biochemical [proline and malondialdehyde (MDA)] responses of five common bush bean (Phaseolus vulgaris L.) cultivars (ICA-Cerinza, ICA-Bachue, NUA35, Bianca, and Bacatá) under a water shortage period by irrigation suspension (15 days) at two different phenological stages [vegetative: $40-55$ days after seed emergence (DAE) or reproductive: (50-65 DAE)]. A completely randomized block design was carried out with a factorial arrangement (the phenological stage as the main factor and the cultivars as the secondary factor) for a total of 10 treatments with four repetitions per treatment. Leaf photosynthesis $\left(P_{n}\right)$ showed equal photosynthesis values in control plants of all cultivars $(\approx 20$ $\left.\mu \mathrm{mol} \cdot \mathrm{m}^{-2} \cdot \mathrm{s}^{-1}\right)$. The water deficit period reduced $P_{n}$ close to $55 \%\left(\approx 12 \mu \mathrm{mol} \cdot \mathrm{m}^{-2} \cdot \mathrm{s}^{-1}\right)$ at both, vegetative, or reproductive stage in all cases. Similar results were also observed on leaf thickness, with a reduction of $\approx 10 \%$ in water-stressed plants at either vegetative or reproductive stage in all evaluated cultivars. A higher MDA and proline production were observed in plants affected by a 15-day water deficit period, mainly at the vegetative stage. The obtained results suggest that the vegetative stage presented a more negative impact on the evaluated physiological variables in most of the cultivars used. Cultivar Bachue showed lower gas exchange properties affectation and higher proline content, which may indicate that this cultivar can be tolerant to water deficit stress conditions. This study allows suggesting that proline and MDA estimation are simple, fast, and lowcost techniques to screen cultivars to obtain more precise breeding selection in common bean. Finally, common bean cultivar selection through the use of biochemical markers can be complemented by the estimation of leaf gas exchange parameters at different phenological stages.
\end{abstract}

The common bean (Phaseolus vulgaris L.) is a small farmers' crop in Latin America (Beebe et al., 2008). In Colombia, P. vulgaris reached a production of 62,974 tons during the first half of 2015 (Fenalce, 2015). It is also a family agricultural activity with a production that generally occurs under conditions of abiotic and biotic stress. For this reason, it is important to select genetically stable materials with higher yield potential (LigarretoMoreno et al., 2015).

Water stress is one of the main problems in bean production, because it can reduce yields by up to $60 \%$ in producer regions worldwide (White and Singh, 1991). In addition, bean cultivation has been displaced to marginal areas in certain agricultural regions due to competition between crops, causing bean plants to be exposed to abiotic stresses such as water and thermal stress (Porch et al., 2007). For instance, beans are mainly culti-

Received for publication 31 July 2019. Accepted for publication 30 Aug. 2019.

H.R.-D. is the corresponding author. E-mail: hrestrepod@unal.edu.co. of biochemical variables also has been very helpful to identify markers of susceptibility and/or tolerance to stress conditions in genotypes (Aranjuelo et al., 2011; Mohamed and Ibrahim, 2011). In this sense, it has been reported that susceptible genotypes accumulate less dry matter and produce different proline concentrations, which means that those genotypes have a better osmotic adjustment (Sánchez-Rodríguez et al., 2010). In addition, water deficit favors MDA production, and higher levels of this biomarker suggest susceptible genotypes (Moussa and Abdel-Aziz, 2008). On the other hand, leaf thickness is another important trait to quantify the effect of water deficit on plant water relations (Scoffoni et al., 2014). Leaf thickness has been used as a physiological indicator to optimize irrigation strategies and characterize genotypes in relation to drought conditions (Seelig et al., 2012).

Physiological breeding is the interaction between common genetic bases and physiological approaches to lead to more precise breeding strategies, generating new cultivars capable of adapting to stressful environments or future climatic conditions (Reynolds and Langridge, 2016). The use of physiological mechanisms as breeding strategies has supported crop genotype identification to abiotic stresses in recent years (Moura et al., 2018; Mwadzingeni et al., 2016; Waqas et al., 2019). In addition, common bean breeding programs have identified that physiological traits (plant growth, photosynthetic pigments, $g_{\mathrm{S}}$, canopy temperature) could be considered as useful selection criteria for drought resistance, because they are simple to measure (Polania et al., 2016).

Based on the previously mentioned, it is important to conduct research to know the physiological behavior of different bush bean genotypes under water deficit. This would allow generating information and tools that contribute to breeding programs (Beebe et al., 2013; Ayala et al., 2013). We hypothesized that common bush bean cultivars showed a superior performance to drought stress because of their greater osmolyte adjustment, lower cell membrane damage, and higher leaf thickness and water use efficiency. For this reason, the objective of this research was to evaluate physiological, biochemical, and anatomical variables as tools for identification of tolerance or susceptibility traits in bush bean (Phaseolus vulgaris L.) genotypes under a severe period of water deficit at two different phenological stages (vegetative vs. reproductive).

\section{Materials and Methods}

the physiological mechanisms involved in acclimation that affect plant behavior and later crop yield (Beebe et al., 2013; Osman, 2015; Winterhalter et al., 2011).

On the other hand, physiological studies with a focus on the use of gas exchange properties [photosynthesis, stomatal conductance $\left(g_{\mathrm{S}}\right)$ and transpiration] have been performed during the past decades to characterize and improve common bean acclimation to water deficit (Beebe et al., 2013). The study

\section{Plant material and growth conditions}

Seeds of five bush bean cultivars were used in the present study. The studied genotypes were the following: 1) ICA-Cerinza and ICA-Bachue are two cultivars that have been sown in traditional Colombian agriculture for 20 years, 2) NUA35 is a cultivar with 7 years of commercialization since its release, and 3) Bianca and Bacatá are two 
cultivars of recent release (less than 2 years). One seed per planting site was sown in the greenhouse of the Faculty of Agricultural Sciences at Universidad Nacional de Colombia located in the city of Bogotá at a height of 2556 meters above sea level (lat. $4^{\circ} 35^{\prime} 56^{\prime \prime} \mathrm{N}$ and long. $74^{\circ} 04^{\prime} 51^{\prime \prime} \mathrm{W}$ ) from Sept. 2015 to Jan. 2016 in $2.1 \mathrm{~m}^{2}$ plots (three rows of 1 linear meter long). The plant spacing was 16 $\mathrm{cm} \times 70 \mathrm{~cm}$ between plants and between rows, respectively (20 seeds per plot $=85,000$ plants/ha). The physicochemical characteristics of the soil in the greenhouse were as follows: 1) sandy loam soil ( $26 \%$ sand, $42 \%$ silt, and $32 \%$ clay); 2 ) chemical characteristics: total nitrogen $0.36 \%$; Ca: $10.6, \mathrm{~K}: 0.98$, $\mathrm{Mg}: 1.75, \mathrm{Na}: 0.24 \mathrm{meq} \cdot 100 \mathrm{~g}^{-1}, \mathrm{Cu}: 1.67, \mathrm{Fe}$ : 310, Mn: 3.21, Zn: 15.5, B: 0.48, and P: $>116$ $\mathrm{mg} \cdot \mathrm{kg}^{-1}$; 3) $\mathrm{pH} 5.4$; and 4) effective cation exchange capacity (ECEC) $13.8 \mathrm{meq} \cdot 100 \mathrm{~g}^{-1}$. Growth conditions in the greenhouse during the experiment were as follows: average temperature $27{ }^{\circ} \mathrm{C}, 60 \%$ to $80 \%$ relative humidity, and a natural photoperiod of $12 \mathrm{~h}$ with photosynthetically active radiation $(P A R)$ of $1000 \mu \mathrm{mol} \cdot \mathrm{m}^{-2} \cdot \mathrm{s}^{-1}$. Plants were fertilized with two edaphic fertilizers: 1) 4 $\mathrm{g} /$ plant $\left(350 \mathrm{~kg} \cdot \mathrm{ha}^{-1}\right)$ of a $15-15-15 \mathrm{com}-$ pound fertilizer (TRIAN 15, Yara, Colombia) as a source of nitrogen, phosphorous, and potassium; 2) and $2 \mathrm{~g} /$ plant $\left(170 \mathrm{~kg} \cdot \mathrm{ha}^{-1}\right)$ of microelements (granulated Agrimins, Colinagro ${ }^{\circledR}$, Colombia) respectively, divided into two applications (half of the aforementioned dose at 15 and 40 DAE). Finally, the composition of the fertilizer Agrimins was total nitrogen $8 \%$ (urea $\mathrm{N} \mathrm{7 \%}$ and ammonium $\mathrm{N}$ $1 \%$ ), assimilable phosphorus $\left(\mathrm{P}_{2} \mathrm{O}_{5}\right) 5.0 \%$, calcium $(\mathrm{CaO}) 18 \%$, magnesium $(\mathrm{MgO}) 6 \%$, total sulfur $1.6 \%$, copper $0.75 \%$, boron $1 \%$, molybdenum $0.005 \%$, and zinc $2.5 \%$.

\section{Water deficit treatment and variable determination}

The bean plants of each cultivar were separated into three different groups to establish the respective treatments. In a first group, plants were subjected to a water deficit period in the phenological stage 13-14 according to the BBCH (Bayer, BASF, Ciba-Geigy, and Hoechst) scale (Feller et al., 1995) (formation of three to four fully expanded trifoliate leaves). This vegetative stage was reached at $\approx 40$ DAE. In the second group, the water deficit period was carried out during the reproductive stage $63-64$ (30\% to $40 \%$ open flowers) at $\approx 50 \mathrm{DAE}$. The third group was control plants (without water deficit during the experiment). The water deficit period was established by the total suspension of irrigation water for $15 \mathrm{~d}$. This period of water stress was selected based on previously developed studies (SánchezReinoso et al., 2018). All plants were irrigated using a watering can. At initial phenological stages (up to 13-14 $\mathrm{BBCH}$ ), plants were irrigated with $6 \mathrm{~mm}$ per week; $12 \mathrm{~mm}$ was supplied per week from 15 to $55 \mathrm{BBCH}$; and $18 \mathrm{~mm}$ was applied per week from 56 to 89 $\mathrm{BBCH}$. The soil moisture content was constantly monitored by a humidity probe (Kel- way HB-2 Soil Acidity and Moisture Tester; Kel Instruments Co., Inc., Wyckoff, NJ) during the stress period.

In general, measurements of all physiological and biochemical variables were performed at the end of each stress period (at 55 DAT for the vegetative stage and 65 DAT for the reproductive stage). Physiological measurements were estimated on the second fully expanded trifoliate leaf from the upper part of the canopy. Regarding biochemical variables, $\approx 2$ g of leaf material were collected, homogenized with liquid nitrogen, and then stored at $-80{ }^{\circ} \mathrm{C}$ until their respective analyzes. Finally, the experiment lasted $\approx 115 \mathrm{~d}$ after the emergence of all seedlings.

\section{Physiological variables}

Water relations and leaf gas exchange. The relative water content (RWC) was determined on fully expanded leaves of the middle part of the canopy. The leaves were collected at the end of the water stress period for each of the evaluated bean genotypes. The RWC was calculated using Eq. [1]:

$$
R W C=\left[\frac{F W-D W}{T W-D W}\right] \times 100
$$

where FW is the fresh weight, TW the measured turgid weight after $24 \mathrm{~h}$ of saturation in distilled water at $4{ }^{\circ} \mathrm{C}$ in the dark, and DW is the dry weight determined after $48 \mathrm{~h}$ in an oven at $70^{\circ} \mathrm{C}$.

Photosynthesis was estimated on the second fully expanded trifoliate leaf from the upper middle portion of the plant using a portable photosynthesis meter (LI-6200; LICOR, Lincoln, NE), between 1000 and 1500 $\mathrm{h}$. This equipment also estimated the internal $\mathrm{CO}_{2}$ concentration. In addition, the ratio of intercellular to ambient $\mathrm{CO}_{2}$ concentration $\left(C_{i} C_{a}\right)$, and stomatal limitations $\left(L_{s}\right)$ were calculated using the equation $L_{s}=1-\left(C_{i} C_{a}\right)$ (Huang et al., 2011). The $g_{\mathrm{S}}$ was determined on the second fully expanded trifoliate leaf with a portable porometer (LI-1600; LICOR). The intrinsic water use efficiency $(i W U E)$ was also calculated as a product of the relationship between photosynthesis and $g_{\mathrm{S}}$. Carboxylation efficiency was calculated by the ratio of photosynthesis and intercellular $\mathrm{CO}_{2}$ concentration $\left(P_{n} / C_{i}\right)$. Gas exchange measurements were performed between 1000 and $1500 \mathrm{~h}$ at 54 to 55 and 64 to $65 \mathrm{DAE}$. During the measurements, the conditions of the liquor chamber were as follows: $P A R$ $1000 \mu \mathrm{mol} \cdot \mathrm{m}^{-2} \cdot \mathrm{s}^{-1}$, leaf temperature $27 \pm$ $5{ }^{\circ} \mathrm{C}$, leaf-to-air vapor pressure difference $1.8 \pm 0.5 \mathrm{kPa}$.

Leaf thickness. The methodology described by Buendía-González et al. (2012) was used to determine leaf thickness. Sections of $1 \mathrm{~cm}^{2}$ taken from the central leaflet of the third fully expanded trifoliate leaf were fixed with an modified Nawaschin's solution CRAF type III composed of two solutions added in a $1: 1 \mathrm{v} / \mathrm{v}$ ratio (solution $\mathrm{A}: 1 \%$ chromic acid, 7\% glacial acetic acid, and 92\% distilled water; solution B: $30 \%$ formalin and $70 \%$ distilled water) for $72 \mathrm{~h}$ dehy- drated in series of EtOH $(70 \%, 80 \%, 85 \%, 90 \%$, $95 \%$ and absolute EtOH) for $24 \mathrm{~h}$ each and rinsed with terbutanol for $24 \mathrm{~h}$. The samples were immersed in a mixture of terbutanol and paraffin (Paraplast plus paraffin at $60^{\circ} \mathrm{C}$ ) in a $1: 1$ $\mathrm{v} / \mathrm{w}$ ratio and in pure paraffin for $24 \mathrm{~h}$ per step (Ortiz et al., 2014). Then, the blocks containing the samples were sectioned in a rotation microtome model Minot 820 Spencer (American Optical, Delhi) with a thickness of $10 \mu \mathrm{m}$. Finally, safranin-fast green staining was performed.

\section{Biochemical variables}

Malondialdehyde. For lipid oxidation (MDA) determination, the thiobarbituric acid method described by Hodges et al. (1999) was used, taking $\approx 30 \mathrm{mg}$ of homogenized plant material and storing it with liquid nitrogen. After centrifuging samples at $3000 \mathrm{~g}_{\mathrm{n}}$, the absorbances at 440, 532, and $600 \mathrm{~nm}$ were estimated with a spectrophotometer (Spectronic BioMate 3 ultraviolet-Vis; Thermo, Madison, WI). Finally, an extinction coefficient $\left(157 \mathrm{M} \cdot \mathrm{mL}^{-1}\right)$ was used to obtain the MDA concentration.

Proline concentration. For proline content determination, the method described by Bates et al. (1973) was used, extracting $\approx 30 \mathrm{mg}$ of homogenized plant material from the second fully expanded trifoliate leaf and storing it with liquid nitrogen. Absorbance was measured at $520 \mathrm{~nm}$ using a spectrophotometer (Spectronic BioMate 3 ultraviolet-Vis; Thermo). Proline content was determined by a standard curve and calculated in fresh weight based on Eq. [2]:

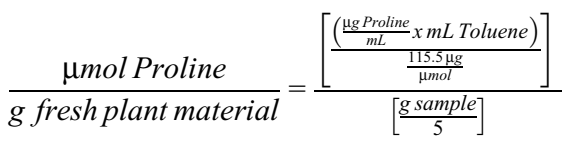

Experimental design and data analysis. A randomized block design was carried out with a factorial arrangement. The first factor was the phenological stage in which drought stress was initiated and the second factor was the five evaluated genotypes, for a total of 10 treatments with four repetitions and a total of 60 plots of $2.1 \mathrm{~m}^{2}$ (three rows of 1 linear meter long). Subsequently, when significant differences were obtained in the analysis of variance (ANOVA), the comparative Tukey test was used at $P \leq 0.05$. Data were analyzed using the Statistix v 9.0 software (analytical software, Tallahassee, FL). The results of the ANOVA are summarized in Table 1.

\section{Results}

Soil moisture, water relations, and leaf gas exchange. In general, the volumetric soil water content (VSWC) in the control treatment was $\approx 90 \%$ field capacity during the test. The VSWC of the other treatments was observed to be close to $55 \%$ at the end of the $15 \mathrm{~d}$ of water deficit initiated at the vegetative stage (55 DAE). In addition, the VSWC of the stressed treatment during the reproductive stage presented $\approx 54 \%$ moisture at 65 DAE (Fig. 1A). The results obtained in the 
quantification of soil moisture indicate that a group of plants had less water availability at some point of their development. Similarly, the results of the leaf RWC are summarized in Fig. 1B. Significant differences were observed only for the water status factor (Table 1). At the 55 DAE sampling, plants that started their stress period at the vegetative stage had $\approx 70 \%$ RWC, compared with control plants, which had values close to $85 \%$. In addition, the plants that began to be subjected to a water deficit at the reproductive stage showed a value of $\approx 77 \%$ at the end of the stress period at that development phase. In the reproductive phase sampling (65 DAE), control plants continued with $\approx 82 \%$ RWC, whereas the plants under stress conditions at the vegetative stage showed values of $\approx 75 \%$ and $73 \%$ in the reproductive phase (Fig. 1B).

Regarding the leaf gas exchange properties [photosynthesis $\left(P_{n}\right), g_{\mathrm{S}}$, and $L_{s}$ ], the results are presented in Fig. 2. Significant differences were found in the interaction between development stage and cultivar in $P_{n}(P \leq 0.05), g_{\mathrm{S}}$, and $L_{s}(P \leq 0.001)$ at the end of each stress period (55 and 65 DAE, respectively). In general, at $55 \mathrm{DAE} P_{n}$ was higher $\left(18.20 \mu \mathrm{mol} \cdot \mathrm{m}^{-2} \cdot \mathrm{s}^{-1}\right)$ in all studied cultivars without water deficit. The $\mathrm{CO}_{2}$ exchange rate was $\approx 45 \%\left(9.07 \mu \mathrm{mol} \cdot \mathrm{m}^{-2} \cdot \mathrm{s}^{-1}\right)$ lower in plants of cultivars Bacatá and Bianca under water stress conditions at both vegetative and reproductive phases. The exception was cultivar Cerinza plants, which showed a reduction of only $\approx 37 \%$ (12.10 $\left.\mu \mathrm{mol} \cdot \mathrm{m}^{-2} \cdot \mathrm{s}^{-1}\right)$ at the vegetative stage and $\approx 17 \%\left(15.80 \mu \mathrm{mol} \cdot \mathrm{m}^{-2} \cdot \mathrm{s}^{-1}\right)$ at the reproductive stage. Finally, $P_{n}$ in plants of cultivar NUA35 had greater reductions of $\approx 42 \%$ $\left(19.13 \mu \mathrm{mol} \cdot \mathrm{m}^{-2} \cdot \mathrm{s}^{-1}\right)$ with stress at the reproductive stage (Fig. 2A). In this sense, it is important to note that bean plants belonging to the water deficit treatment during the reproductive stage had already undergone a 5 -day period of low humidity availability in the soil at the time of measurement. Trends similar to those observed in the previous sampling were obtained with measurements performed at 65 DAE. Control plants of all cultivars presented equal photosynthesis values among them $\left(\approx 20 \mu \mathrm{mol} \cdot \mathrm{m}^{-2} \cdot \mathrm{s}^{-1}\right)$. On the other hand, a water deficit period reduced $P_{n}$ close to $55 \%\left(\approx 12 \mu \mathrm{mol} \cdot \mathrm{m}^{-2} \cdot \mathrm{s}^{-1}\right)$ both at the vegetative or reproductive stage in all cases (Fig. 2B). Regarding $g_{\mathrm{S}}$, this variable was also higher in control treatment plants, which recorded values $\approx 0.30 \mu \mathrm{mol} \cdot \mathrm{m}^{-2} \cdot \mathrm{s}^{-1}$ and $0.50 \mu \mathrm{mol} \cdot \mathrm{m}^{-2} \cdot \mathrm{s}^{-1}$ at 55 and $65 \mathrm{DAE}$, respectively. A 15-day period of water deficit at the vegetative or reproductive phase also caused a negative affectation in this gas exchange variable. In general, $g_{\mathrm{S}}$ was $35 \%$ lower in all cultivars $\left(\approx 0.21 \mu \mathrm{mol} \cdot \mathrm{m}^{-2} \cdot \mathrm{s}^{-1}\right.$ at $55 \mathrm{DAE}$ and $\approx 0.33 \mu \mathrm{mol} \cdot \mathrm{m}^{-2} \cdot \mathrm{s}^{-1}$ at $65 \mathrm{DAE}$ ) in both samplings (Fig. 2C and D). Finally, stomatal limitation (Fig. 2E and F) remained generally constant in most cultivars $\left(L_{s} \approx 0.29\right)$ at 55 DAE, except for cultivar NUA35 plants that showed a higher value in both water deficit periods $\left(L_{s} \approx 0.33\right)$ (Fig. $\left.2 \mathrm{E}\right)$. $L_{s}$ was higher specifically in 'Cerinza' bean plants subjected to a 15-day period of water deficit during the reproductive stage at $65 \mathrm{DAE}\left(L_{s}\right.$ under stress: 0.27 and $L s$ Control: 0.21). However, cultivars Bachue, NUA35, Bacatá, and Bianca (0.24) maintained values close to those found in the control plants $(0.25)$ (Fig. 2F).

On the other hand, Table 2 summarizes the results of the intrinsic water use efficiency (iWUE), ratio of intercellular to ambient $\mathrm{CO}_{2}$ $\left(C_{i} / C_{a}\right)$, and carboxylation efficiency $\left(P_{n} / C_{i}\right)$, respectively. For the $i W U E$, only the significant

Table 1. Summary of the analysis of variance of the effects of water deficit stress on the physiological behavior and performance parameters in five bush bean genotypes.

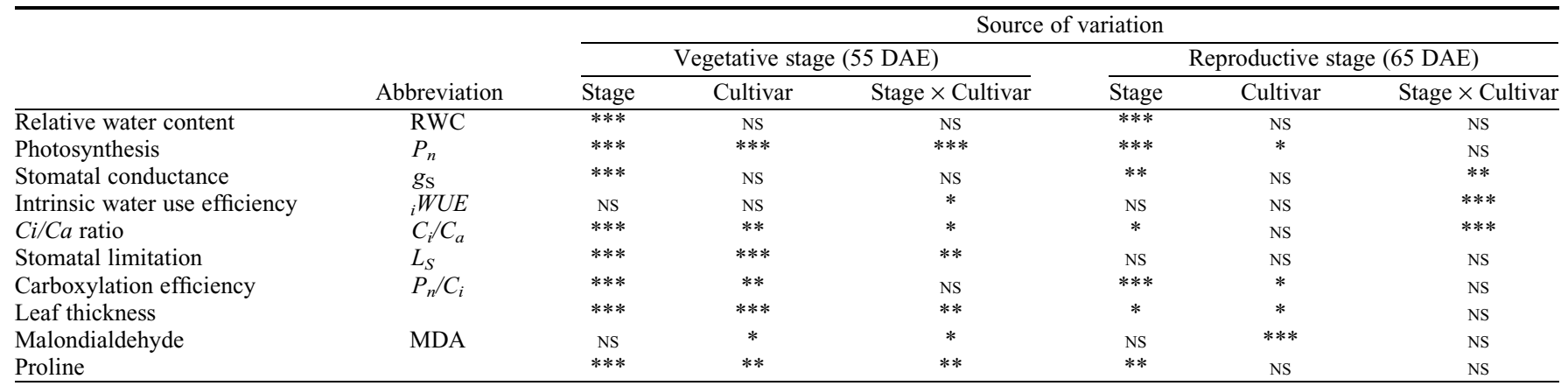

$*, * *, * * *$ Significantly different at probability levels of $0.05,0.01$, or 0.001 , respectively. Ns, not significant with $a=0.05$. DAE $=$ days after emergence.

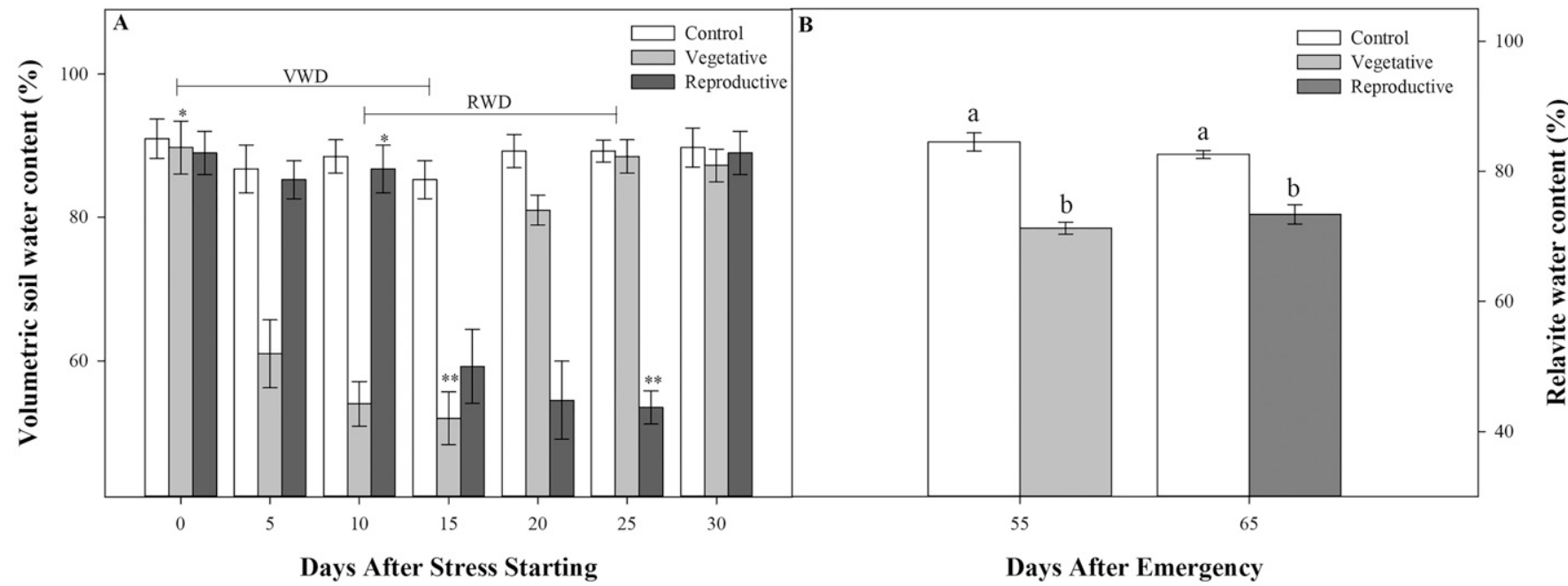

Fig. 1. Effect of water deficit stress on volumetric soil water content and leaf relative water content of five bush bean genotypes. Bars represent \pm SE. VWD $=$ vegetative water deficit; RWD = reproductive water deficit. *Indicates the beginning of the stress period in each evaluated stage. ${ }^{* *}$ Indicates the end of the stress period and the beginning of the rehydration of plants in each evaluated stage. 


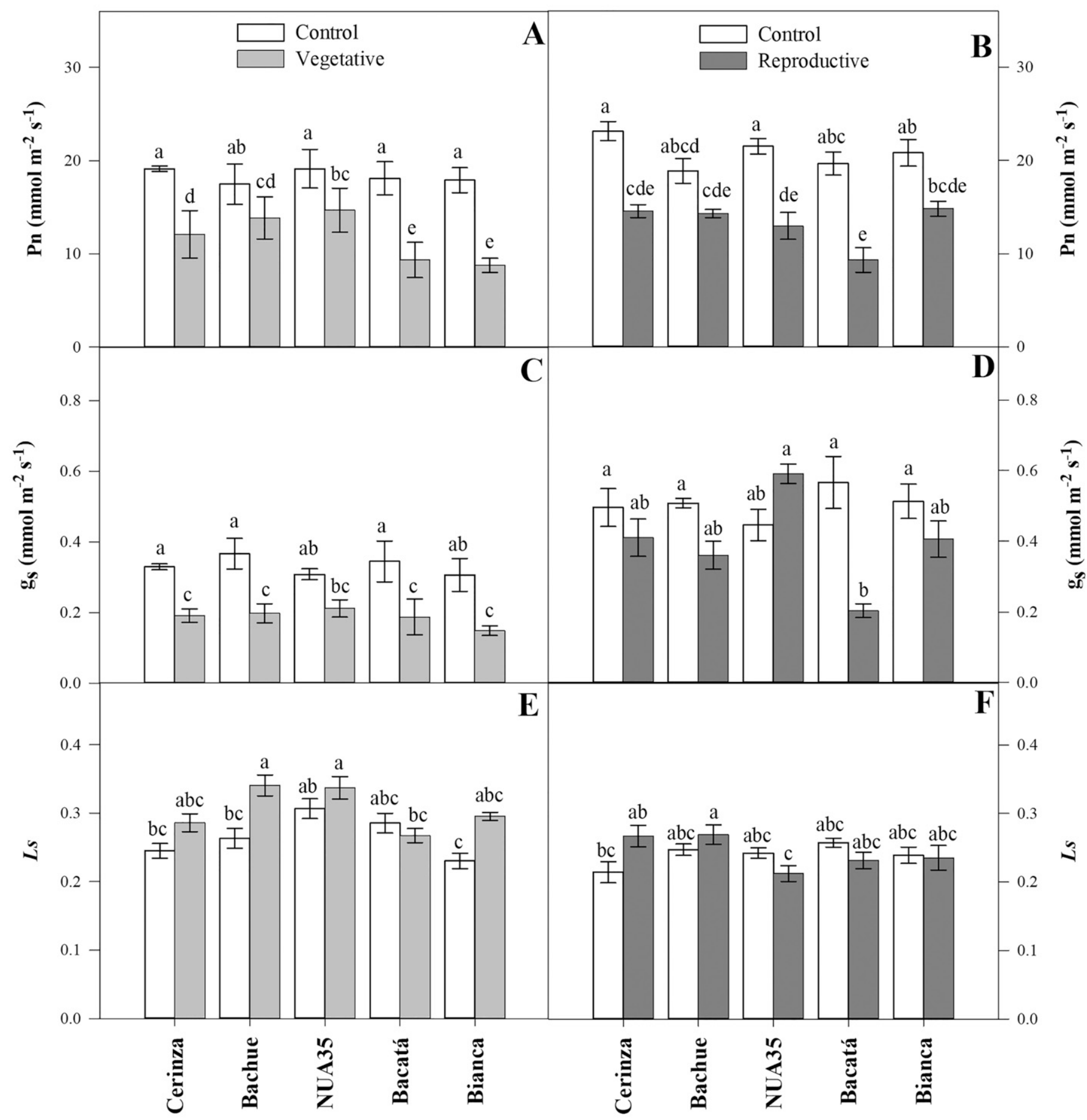

Fig. 2. Effect of water deficit stress on photosynthesis $\left(P_{n}\right)(\mathbf{A}$ and $\mathbf{B})$, stomatal conductance $\left(g_{\mathrm{S}}\right)(\mathbf{C}$ and $\mathbf{D})$, and stomatal limitation $\left(L_{s}\right)(\mathbf{E}$ and $\mathbf{F})$ of five bush bean cultivars at vegetative $[55 \mathrm{~d}$ after emergence (DAE)] or reproductive (65 DAE) stages. Bars represent the mean of four values $\pm \mathrm{SE}$.

differences obtained in the interaction stage $\times$ cultivar at the end of the water deficit stress period in the reproductive stage (65 DAE) are highlighted. In this sense, cultivars Bachue, Bacatá, and Bianca showed the highest $i W U E$ values when the water deficit stress period was carried out during the reproductive stage (45.21, 44.16, and $41.24 \mu \mathrm{mol} \mathrm{CO}_{2} / \mathrm{mmol}$ $\mathrm{H}_{2} \mathrm{O}$, respectively), whereas cultivars NUA35 and Cerinza showed the lowest results when the stress period ended at 65 DAE (21.37 and $39.79 \mu \mathrm{mol} \mathrm{CO}_{2} / \mathrm{mmol} \mathrm{H}_{2} \mathrm{O}$, respectively). However, cultivar NUA35 significantly reduced $i W U E$ by $50 \%$ compared with control plants. As for the $C_{i} / C_{a}$ ratio, statistical differences were obtained in the cultivar factor at 55 DAE, whereas differences were evidenced in the stage factor at 65 DAE. Consequently, when the stress started in the vegetative stage (55 DAE), cultivar NUA35 plants presented the lowest $C_{i} / C_{a}$ values $(\approx 0.69)$ and the rest of the cultivars presented average values of 0.71 in this variable (Table 2). In addition, plants under water deficit in the reproductive stage had values similar to plants under control conditions $\left(C_{i} / C_{a}\right.$ of 0.76$)$ at 65 DAE (Table 2).

Differences in the interaction stage $x$ cultivar $(P \leq 0.05)$ were found on the carboxylation efficiency $\left(P_{n} / C_{i}\right)$ at $55 \mathrm{DAE}$, whereas significant differences were found in the factors stage and cultivar at 65 DAE. 
When stress ended at 55 DAE, cultivars Cerinza, Bacatá, and Bianca plants evaluated under stress conditions in the vegetative stage showed a reduction close to $30 \%$ of the $P_{n} / C_{i}$ compared with the plants under control conditions. However, when the stress period ended at $65 \mathrm{DAE}$, it was evident that the vegetative stage reached the lowest $P_{n} / C_{i}$ values with a reduction greater than $50 \%$ $\left(\approx 0.03 \mathrm{~mol} \cdot \mathrm{m}^{-2} \cdot \mathrm{s}^{-1}\right)$ compared with control plants $\left(0.07 \mathrm{~mol} \cdot \mathrm{m}^{-2} \cdot \mathrm{s}^{-1}\right)$. This indicated the evaluated bean plants had a greater susceptibility in this growth point with cultivar Bacatá showing the lowest $P_{n} / C_{i}$ values $\left(0.04 \mathrm{~mol} \cdot \mathrm{m}^{-2} \cdot \mathrm{s}^{-1}\right)$. However, the plants that were under stress conditions in the reproductive stage showed $P_{n} / C_{i}$ values of 0.04 $\mathrm{mol} \cdot \mathrm{m}^{-2} \cdot \mathrm{s}^{-1}$ (Table 2 ).
Leaf thickness. Table 3 and Fig. 3 summarize the results found in the leaf thickness of the five bush bean cultivars under water deficit conditions in two phenological stages. Significant differences were found in the interaction cultivar $\times$ stage when stress was evaluated in the vegetative stage (55 DAE). In contrast, significant differences were found in the factors stage and cultivar at 65

Table 2. Effect of water deficit stress on leaf gas exchange parameters of five bush bean genotypes at two different phenological stages [ 55 or $65 \mathrm{~d}$ after emergence (DAE)].

\begin{tabular}{|c|c|c|c|c|c|c|c|}
\hline \multirow[b]{2}{*}{ Treatment } & \multicolumn{3}{|c|}{ Vegetative stage (55 DAE) } & \multirow[b]{2}{*}{ Treatment } & \multicolumn{3}{|c|}{ Reproductive stage (65 DAE) } \\
\hline & $\begin{array}{c}{ }_{i} W U E \\
\left(\mu \mathrm{mol} \cdot \mathrm{mmol}^{-1} \mathrm{H}_{2} \mathrm{O}\right)\end{array}$ & $C_{i} / C_{a}$ & $\begin{array}{c}P_{n} / C_{i} \\
\left(\mathrm{~mol} \cdot \mathrm{m}^{-2} \cdot \mathrm{s}^{-1}\right)\end{array}$ & & $\begin{array}{c}{ }_{i} W U E \\
\left(\mu \mathrm{mol} \cdot \mathrm{mmol}^{-1} \mathrm{H}_{2} \mathrm{O}\right)\end{array}$ & $C_{i} / C_{a}$ & $\begin{array}{c}P_{n} / C_{i} \\
\left(\mathrm{~mol} \cdot \mathrm{m}^{-2} \cdot \mathrm{s}^{-1}\right) \\
\end{array}$ \\
\hline Stage of stress & & & & Stage of stress & & & \\
\hline Control & 57.45 & $0.73 \mathrm{a}^{\mathrm{z}}$ & $0.06 \mathrm{a}$ & Control & $42.65 \mathrm{a}$ & 0.76 & $0.07 \mathrm{a}$ \\
\hline Vegetative (Veg) & 60.53 & $0.69 \mathrm{~b}$ & $0.04 \mathrm{~b}$ & Reproductive (Rep) & $38.35 \mathrm{~b}$ & 0.76 & $0.04 \mathrm{~b}$ \\
\hline Significance & $\mathrm{NS}^{\mathrm{y}}$ & $* * *$ & $* * *$ & Significance & $*$ & NS & $* * *$ \\
\hline Cultivar & & & & Cultivar & & & \\
\hline Cerinza & 55.26 & $0.73 \mathrm{a}$ & $0.05 \mathrm{ab}$ & Cerinza & $43.72 \mathrm{a}$ & 0.78 & $0.06 \mathrm{a}$ \\
\hline Bachue & 58.81 & $0.70 \mathrm{ab}$ & $0.06 \mathrm{ab}$ & Bachue & $41.32 \mathrm{ab}$ & 0.77 & $0.05 \mathrm{ab}$ \\
\hline NUA35 & 65.55 & $0.68 \mathrm{~b}$ & $0.06 \mathrm{a}$ & NUA35 & $35.84 \mathrm{~b}$ & 0.78 & $0.05 \mathrm{ab}$ \\
\hline Bacatá & 54.15 & $0.72 \mathrm{a}$ & $0.05 \mathrm{ab}$ & Bacatá & $40.33 \mathrm{ab}$ & 0.77 & $0.04 \mathrm{~b}$ \\
\hline Bianca & 61.34 & $0.74 \mathrm{a}$ & $0.04 \mathrm{~b}$ & Bianca & $41.10 \mathrm{ab}$ & 0.77 & $0.05 \mathrm{ab}$ \\
\hline Significance & NS & $* *$ & $* *$ & Significance & NS & NS & $*$ \\
\hline Interaction & & & & Interaction & & & \\
\hline Control $\times$ Cerinza & $58.15 \mathrm{abc}$ & $0.76 \mathrm{ab}$ & $0.06 \mathrm{ab}$ & Control $\times$ Cerinza & $48.05 \mathrm{ab}$ & 0.79 & 0.07 \\
\hline Control $\times$ Bachue & $48.21 \mathrm{c}$ & $0.74 \mathrm{ab}$ & $0.06 \mathrm{ab}$ & Control $\times$ Bachue & $37.42 \mathrm{c}$ & 0.75 & 0.06 \\
\hline Control $\times$ NUA35 & $61.71 \mathrm{ab}$ & $0.69 \mathrm{bc}$ & $0.07 \mathrm{a}$ & Control $\times$ NUA35 & $50.32 \mathrm{a}$ & 0.74 & 0.07 \\
\hline Control × Bacatá & $55.70 \mathrm{bc}$ & $0.71 \mathrm{abc}$ & $0.07 \mathrm{ab}$ & Control × Bacatá & $36.51 \mathrm{c}$ & 0.74 & 0.07 \\
\hline Control $\times$ Bianca & $63.50 \mathrm{ab}$ & $0.77 \mathrm{a}$ & $0.06 \mathrm{ab}$ & Control $\times$ Bianca & $40.95 \mathrm{abc}$ & 0.76 & 0.07 \\
\hline Veg $\times$ Cerinza & $52.08 \mathrm{bc}$ & $0.71 \mathrm{abc}$ & $0.04 \mathrm{bc}$ & Rep $\times$ Cerinza & $39.79 \mathrm{bc}$ & 0.73 & 0.05 \\
\hline Veg $\times$ Bachue & $69.40 \mathrm{a}$ & $0.66 \mathrm{c}$ & $0.05 \mathrm{abc}$ & Rep $\times$ Bachue & $45.21 \mathrm{abc}$ & 0.73 & 0.05 \\
\hline Veg $\times$ NUA35 & $69.39 \mathrm{a}$ & $0.66 \mathrm{c}$ & $0.06 \mathrm{ab}$ & Rep $\times$ NUA35 & $21.37 \mathrm{~d}$ & 0.79 & 0.04 \\
\hline Veg $\times$ Bacatá & $52.59 \mathrm{bc}$ & $0.73 \mathrm{abc}$ & $0.03 \mathrm{c}$ & Rep $\times$ Bacatá & $44.16 \mathrm{abc}$ & 0.77 & 0.03 \\
\hline Veg $\times$ Bianca & $59.18 \mathrm{abc}$ & $0.70 \mathrm{abc}$ & $0.03 \mathrm{c}$ & Rep $\times$ Bianca & $41.24 \mathrm{abc}$ & 0.76 & 0.05 \\
\hline Significance & $*$ & $*$ & $*$ & Significance & $* * *$ & NS & NS \\
\hline $\mathrm{CV}(\%)^{\mathrm{x}}$ & 15.38 & 4.38 & 17.79 & CV $(\%)^{x}$ & 16.02 & 7.11 & 13.61 \\
\hline
\end{tabular}

${ }^{\mathrm{z}}$ Values within a column followed by different letters are significantly different at $P \leq 0.05$ according to the Tukey test.

${ }^{\mathrm{y}} \mathrm{NS}=$ not significant $(P \leq 0.05) .{ }^{*},{ }^{* *},{ }^{* * *}$ Significant at $P \leq 0.05,0.01$, or 0.001 , respectively.

${ }^{\mathrm{x}} \mathrm{CV}=$ coefficient of variation

Table 3. Effect of water deficit stress on leaf thickness of five bush bean genotypes at two different phenological stages [55 or $65 \mathrm{~d}$ after emergence (DAE)].

\begin{tabular}{|c|c|c|c|}
\hline & Vegetative stage (55 DAE) & & Reproductive stage (65 DAE) \\
\hline Treatment & $\overline{\text { Leaf thickness }(\mu \mathrm{m})}$ & Treatment & Leaf thickness $(\mu \mathrm{m})$ \\
\hline Control & $190.58 \mathrm{a}^{\mathrm{z}}$ & Control & $190.88 \mathrm{a}$ \\
\hline Cultivar & & Cultivar & \\
\hline Cerinza & $210.78 \mathrm{a}$ & Cerinza & $195.46 \mathrm{a}$ \\
\hline Bachue & $184.42 \mathrm{~b}$ & Bachue & $190.89 \mathrm{ab}$ \\
\hline Bianca & $167.96 \mathrm{bc}$ & Bianca & $182.08 \mathrm{ab}$ \\
\hline Significance & $* * *$ & Significance & $*$ \\
\hline Interaction & & Interaction & \\
\hline Control $\times$ Cerinza & $205.12 \mathrm{a}$ & Control $\times$ Cerinza & 195.62 \\
\hline Control $\times$ Bachue & $208.72 \mathrm{a}$ & Control $\times$ Bachue & 202.59 \\
\hline Control $\times$ NUA35 & $186.81 \mathrm{ab}$ & Control $\times$ NUA35 & 195.00 \\
\hline Control $\times$ Bacatá & $187.05 \mathrm{ab}$ & Control $\times$ Bacatá & 169.67 \\
\hline Veg $\times$ Bianca & $145.70 \mathrm{c}$ & Rep $\times$ Bianca & 172.66 \\
\hline Significance & $* *$ & Significance & $\mathrm{NS}^{\mathrm{y}}$ \\
\hline $\mathrm{CV}(\%)^{\mathrm{x}}$ & 9.07 & $\operatorname{CV}(\%)^{\mathrm{x}}$ & 11.99 \\
\hline
\end{tabular}

${ }^{\mathrm{z}}$ Values within a column followed by different letters are significantly different at $P \leq 0.05$ according to the Tukey test.

$\mathrm{y}_{\mathrm{NS}}=$ not significant $(P \leq 0.05){ }^{*}, * * * * *$ Significant at $P \leq 0.05,0.01$, or 0.001 , respectively.

${ }^{\mathrm{x}} \mathrm{CV}=$ coefficient of variation. 


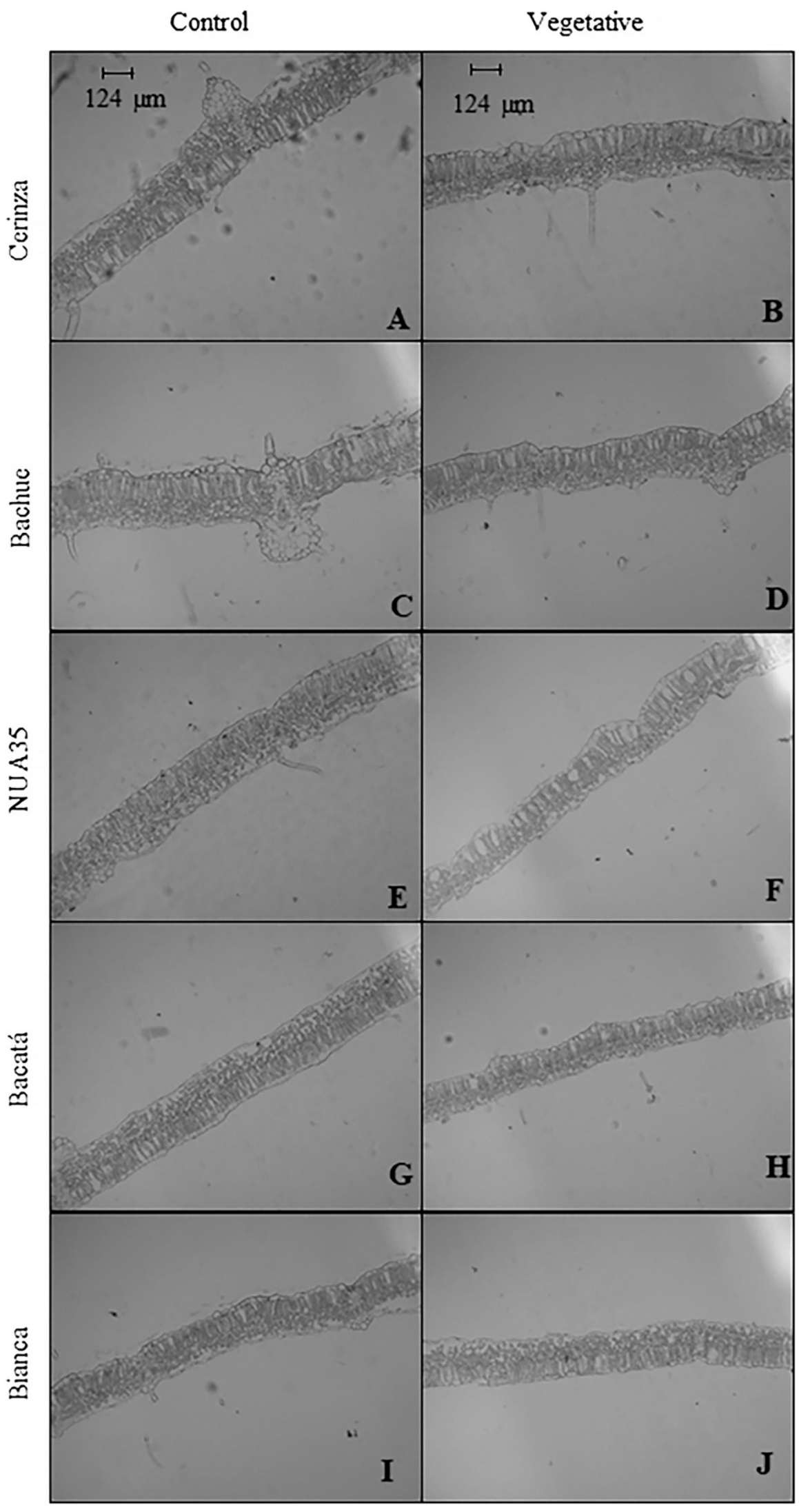

Fig. 3. Effect of water deficit stress on the leaf thickness in cuttings of cultivar Cerinza (A and $\mathbf{B}$ ), Bachue $(\mathbf{C}$ and $\mathbf{D})$, NUA35 (E and $\mathbf{F})$, Bacatá ( $\mathbf{G}$ and $\mathbf{H})$, and Bianca (I and $\mathbf{J})$ under control and stress conditions at vegetative stage, respectively.

DAE. At the end of the vegetative stage stress (55 DAE), differences in the observed data for the leaf thickness were found among the evaluated cultivars, being cultivar Cerinza the one with the highest value $(204.69 \mu \mathrm{m})$, followed by Bachue, NUA35, Bacatá, and
Bianca $(189.00 \mu \mathrm{m}, 171.96 \mu \mathrm{m}, 269.13 \mu \mathrm{m}$, and $156.47 \mu \mathrm{m}$, respectively). In addition, under conditions of water deficit stress during the vegetative stage, cultivar Bachue showed a reduction in the leaf thickness close to $23 \%$ compared with control plants $(160.12 \mu \mathrm{m}$ and $208.72 \mu \mathrm{m}$, respectively). On the other hand, at the end of the stress period during the reproductive stage (65 DAE), it was evident that plants of the cultivars that were under stress conditions showed lower leaf thickness values (average of $173.21 \mu \mathrm{m}$ ), whereas control plant values were close to $190 \mu \mathrm{m}$.

MDA and proline concentration. Regarding membrane damage by oxidative stress and osmolytes production, the results of MDA and proline production are shown in Fig. 4A-D. Significant differences also were observed between the treatments in the aforementioned variables on the interaction stress stage $\times$ cultivar $(P \leq 0.001$ at $55 \mathrm{DAE}$ and $P \leq 0.05$ at $65 \mathrm{DAE})$. Cultivar Cerinza plants with water stress during the vegetative phenological stage had the highest MDA production at 55 DAE (with values close to $\left.14 \mu \mathrm{mol} \cdot \mathrm{g}^{-1} \mathrm{FW}\right)$. Then, cultivars Bacatá $\left(8.90 \mu \mathrm{mol} \cdot \mathrm{g}^{-1} \mathrm{FW}\right)$ and Bianca (6.54 $\mu \mathrm{mol} \cdot \mathrm{g}^{-1} \mathrm{FW}$ ) also had an increase in MDA production close to $30 \%$ compared with their controls (5.77 and $6.85 \mu \mathrm{mol} . \mathrm{g}^{-1} \mathrm{PF}$, respectively) (Fig. 4A). At 65 DAE, MDA production was especially higher in the cultivar Bacatá under stress conditions at the reproductive stage $\left(6.37 \mu \mathrm{mol} \cdot \mathrm{g}^{-1} \mathrm{FW}\right)$, followed by cultivar Cerinza, which was subjected to deficit at the vegetative stage $\left(5.96 \mu \mathrm{mol} \cdot \mathrm{g}^{-1}\right.$ PF) (Fig. 4B). Proline production was favored under stress conditions at the vegetative and reproductive stages in both sampling points (55 and 65 DAE, respectively). Bachue was the cultivar with the highest MDA production $\left(\approx 76\right.$ and $58 \mu \mathrm{mol} \cdot \mathrm{g}^{-1} \mathrm{FW}$ for the vegetative and reproductive stage, respectively, at 55 DAE). Finally, proline contents were generally lower at $65 \mathrm{DAE}$ compared with those observed at 55 DAE. In this sense, a lower proline content was registered in the cultivars during water deficit in the second sampling point (65 DAE). Cultivars Cerinza, NUA35, Bacatá, and Bianca went from an average proline content of $40 \mu \mathrm{mol} \cdot \mathrm{g}^{-1} \mathrm{FW}$ in control plants to values of $51 \mu \mathrm{mol} \cdot \mathrm{g}^{-1} \mathrm{FW}$ under drought conditions during the reproductive stage (Fig. 4C and D).

\section{Discussion}

The use of the VSWC is an important tool to monitor water deficit stress in bean plants. It has been considered that a reduction of at least $50 \%$ in the values of soil volumetric water content compared with control conditions causes stress levels due to water deficit in wheat plants, which is similar to data obtained in the present study (Liu et al., 2017). In addition, it has been shown that a reduction in the leaf RWC as a consequence of moderate water deficit stress has a significant effect on the physiological parameters of bean plants (Soltys-Kalina et al., 2016), which matches what was found in our study. 


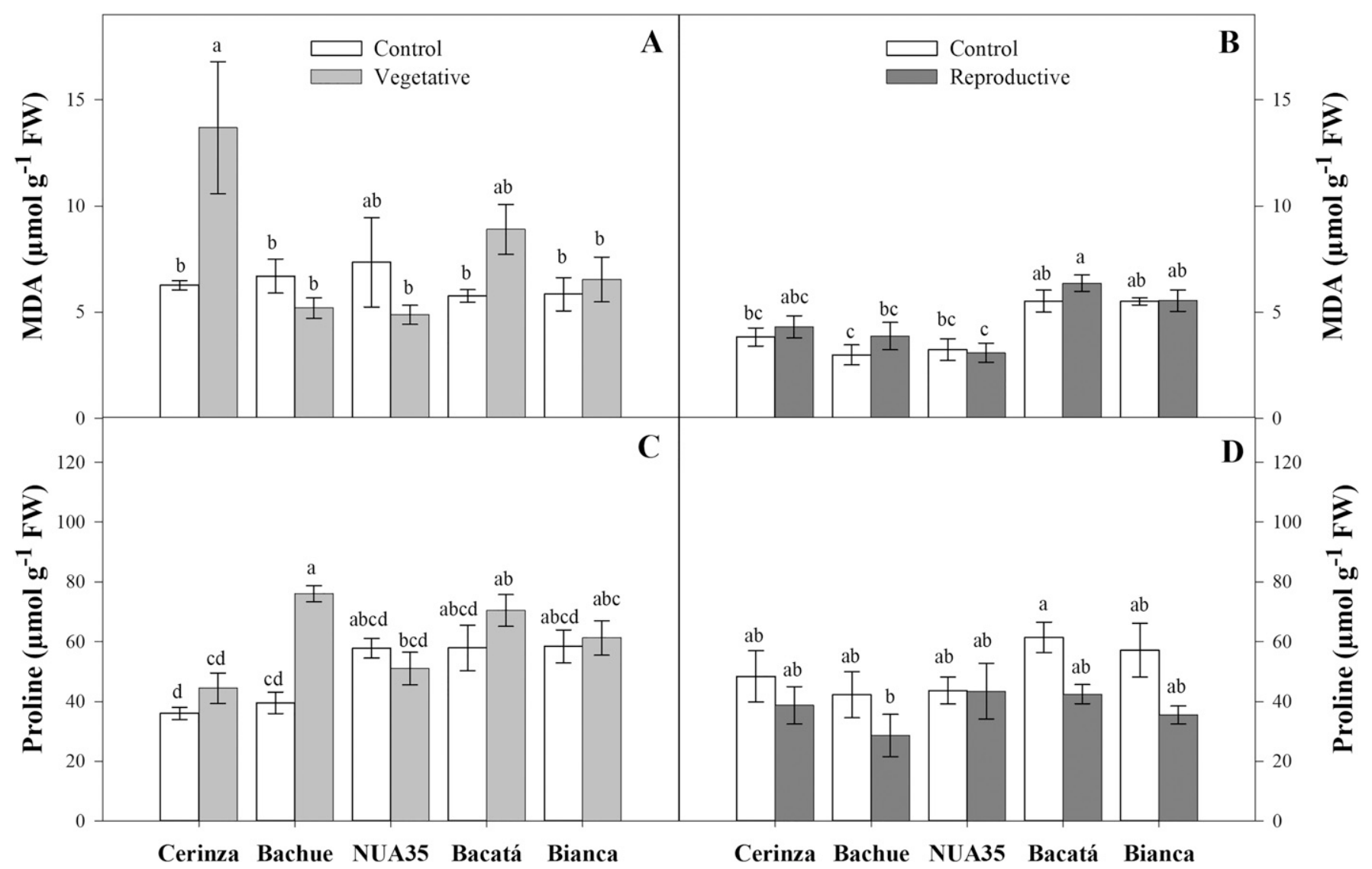

Fig. 4. Effect of water deficit stress on malondialdehyde production ( $\mathbf{A}$ and $\mathbf{B})$ and proline production $(\mathbf{C}$ and $\mathbf{D})$ of five bush bean cultivars at vegetative $[55 \mathrm{~d}$ after emergence (DAE)] or reproductive (65 DAE) stages. Bars represent the mean of four values $\pm \mathrm{SE}$.

Our results showed that the decrease in the leaf thickness of the evaluated bush bean plants was a response to water deficit, especially in cultivar Bachue in the vegetative stage. The reduction in the leaf thickness under water deficit conditions may be due to the loss of turgor in cells caused by a decrease in the plant water potential. This is reflected in the low RWC values in the leaf (Scoffoni et al., 2014), which agrees with the results of our experiment (Figs. 1 and 3). In addition, these morpho-anatomical changes in the leaf indicate a phenotypic plasticity due to differences in environmental conditions, such as drought, which is one of the important features of the species involved in the mechanisms of water deficit tolerance (Matzner et al., 2019).

Regarding leaf gas exchange properties, most of bean plants under conditions of water deficit stress may present stomatal and nonstomatal limitations of photosynthesis, which depend on the severity and duration of the stress (Mathobo et al., 2017). In addition, the reduction of the photosynthetic rate may be greater when plants are at vegetative stages (Rosales et al., 2012). In this sense, our results suggest that the evaluated bush bean cultivars present stomatal limitations of photosynthesis with $15 \mathrm{~d}$ of water deficit at the vegetative stage as an initial response of plants to the low water availability in the soil (Drake et al., 2017). This is evidenced in the reduction of the photosynthetic rate and $g_{\mathrm{S}}$ of bean plants. It is well documented that water deficit causes stomatal closure because of a higher abscisic acid production (Pang et al., 2016). However, when cultivar NUA35 was under water deficit stress conditions during the reproductive stage, it showed a reduction in $P_{n}$, despite not showing a significant reduction in $g_{\mathrm{S}}$. In addition, it could be observed that there was an accumulation of intercellular carbon in the leaves of this cultivar, which suggests that cultivar NUA35 presented nonstomatal limitations of photosynthesis (Table 2). These genotypic differences in the gas exchange properties obtained in our results may be related to the level of oxidative stress of bush bean plants, as reported in tomato plants (Sánchez-Rodríguez et al., 2010). Consequently, one of the parameters that helped us to identify the degree of susceptibility to oxidative stress damage in bush bean cultivars was the determination of the MDA content, especially at the vegetative stage. It has been shown that the increase in the MDA concentration in Phaseolus vulgaris plants is related to traits of susceptibility to water deficit conditions as a result of the increased production of oxygen free radicals that generate oxidative stress in cells (Kusvuran and Dasgan, 2017). In this sense, our results suggest that cultivars Cerinza and Bacatá showed the highest levels of damage by lipid peroxidation of cell membranes under water deficit conditions at the vegetative stage (Fig. 4), indicating a degree of susceptibility to the stressful condition. On the other hand, although cultivars Bachue and NUA35 showed a lower MDA production when plants were under water deficit at the vegetative stage, cultivar Bachue presented an increase in proline content, which indicates that the production of this amino acid can be a relief strategy to the oxidative stress. There is a correlation between proline accumulation and tolerance to water deficit conditions in bean plants, because a high proline concentration acts as an osmoprotector (Chen et al., 2016). In contrast, it was found that a 15-day period of water deficit stress at the reproductive stage did not generate a negative impact on the stability of the cell membrane, which indicates that at this phenological stage, the damage levels are lower compared with the vegetative phase (Mathobo et al., 2017).

In conclusion, the responses in the physiological behavior of the evaluated bush bean cultivars under a 15-day period of water deficit conditions at the vegetative and reproductive stages indicate that there are 
differences between cultivars in the level of susceptibility and/or tolerance to the stressful condition. These characteristics are related to the acclimation mechanisms of bush bean plants that involve avoidance and tolerance strategies. In addition, it was emphasized that the vegetative stage presented a higher level of negative impact on the evaluated physiological variables in most of the cultivars used in the present study. In this sense, it was found that cultivar Bacatá presented stomatal and nonstomatal limitations of photosynthesis when the stress period started at the vegetative phase. These traits may indicate this cultivar can be susceptible to water deficit stress conditions. On the other hand, cultivar Bachue showed lower affectation of gas exchange properties and higher proline content, which may indicate that this cultivar can be tolerant to water deficit stress conditions. As we hypothesized, this study allows suggesting that proline and MDA estimation are simple, fast, and low-cost techniques to screen cultivars to obtain more precise breeding selection in common bean. Finally, common bean cultivar selection through the use of biochemical markers can be complemented by the estimation of leaf gas exchange parameters at different phenological stages.

\section{Literature Cited}

Aranjuelo, I., G. Molero, G. Erice, J.C. Avice, and S. Nogués. 2011. Plant physiology and proteomics reveals the leaf response to drought in alfalfa (Medicago sativa L.). J. Expt. Bot. 62:111-123.

Ayala, C.C., A. Jarma-Orozco, and H. AramendizTatis. 2013. Mecanismos de adaptación a sequía en caupí (Vigna unguiculata (L.) Walp.). Una revisión. Rev. Colomb. Cienc. Hort 7(2):277-288.

Bates, L., R. Waldren, and I. Teare. 1973. Rapid determination of free proline for water-stress studies. Plant Soil 39:205-207.

Beebe, S.E., I.M. Rao, C. Cajiao, and M. Grajales. 2008. Selection for drought resistance in common bean also improves yield in phosphorus limited and favorable environments. Crop Sci. 48:582-592.

Beebe, S.E., I.M. Rao, M.W. Blair, and J.A. AcostaGallegos. 2013. Phenotyping common beans for adaptation to drought. Front. Physiol. 4:35.

Buendía-González, L., M.E. Estrada-Zúñiga, J Orozco-Villafuerte, F. Cruz-Sosa, and E.J. Vernon-Carter. 2012. Somatic embryogenesis of the heavy metal accumulator Prosopis laevigata. Plant Cell Tiss. Org. 108:287-296.

Chen, J., J. Wu, Y. Lu, Y. Cao, H. Zeng, Z. Zhang, L. Wang, and S. Wang. 2016. Molecular cloning and characterization of a gene encoding the proline transporter protein in common bean (Phaseolus vulgaris L.). Crop J. 4:384-390.

Drake, J.E., S.A. Power, R.A. Duursma, B.E. Medlyn, M.J. Aspinwall, B. Choat, D. Creek, D. Eamus, C. Maier, S. Pfautsch, R.A. Smith, M.G. Tjoelker, and D.T. Tissue. 2017. Stomatal and non-stomatal limitations of photosynthesis for four tree species under drought: A comparison of model formulations. Agr. For. Meteorol. 247:454-466.

Farooq, M., M. Hussain, A. Wahid, and K.H.M. Siddique. 2012. Drought stress in plants: An overview, p. 1-33. In: R. Aroca (ed.). Plant responses to drought stress. Springer, Berlin.

Feller, C., H. Bleiholder, L. Buhr, H. Hack, M. Hess, R. Klose, U. Meier, R. Stauss, T. Van den Boom, and E. Weber. 1995. Phänologische Entwicklungsstadien von Gemüsepflanzen: II. Fruchtgemüse und Hülsenfrüchte. Nachrichtenbl. Deut. Pflanzenschutzd. 47:217-232.

Fenalce. 2015. Informe de Gestión año 2015. 10 Aug. 2019. <www.fenalce.org/nueva/plantillas/arch web/Salida_de_cosecha_leguminosas.pdf $>$.

Hodges, D.M., J.M. DeLong, C.F. Forney, and R.K. Prange. 1999. Improving the thiobarbituric acidreactive-substances assay for estimating lipid peroxidation in plant tissues containing anthocyanin and other interfering compounds. Planta 207:604-611.

Huang, Z., Z. Zou, C. He, Z. He, Z. Zhang, and J. Li. 2011. Physiological and photosynthetic responses of melon (Cucumis melo L.) seedlings to three Glomus species under water deficit. Plant Soil 339:391-399.

Kusvuran, S. and H.Y. Dasgan. 2017. Effects of drought stress on physiological and biochemical changes in Phaseolus vulgaris L. Legume Res. 40:55-62.

Li, R., Q. Min, and Y. Fu. 2011. 1997/98 El Niñoinduced changes in rainfall vertical structure in the east Pacific. J. Clim. 24:6373-6391.

Ligarreto-Moreno, G.A., O.A. Castro, and B. Cháves. 2015. Phenotypic stability of shrub bean (Phaseolus vulgaris 1.) collection. Rev. Udca Actual. Divulg. Cient. 18:109-118.

Liu, S., X. Li, D.H. Larsen, X. Zhu, F. Song, and F. Liu. 2017. Drought priming at vegetative growth stage enhances nitrogen-use efficiency under post-anthesis drought and heat stress in wheat. J. Agron. Crop Sci. 203:29-40.

Mathobo, R., D. Marais, and J.M. Steyn. 2017. The effect of drought stress on yield, leaf gaseous exchange and chlorophyll fluorescence of dry beans (Phaseolus vulgaris L.). Agr. Water Manage. 180:118-125.

Matzner, S.L., N. Ronning, J. Hawkinson, T. Cummiskey, J. Buchanan, E. Miller, and G. Carlisle. 2019. Does acclimation in cavitation resistance due to mechanical perturbation support the pit area or conduit reinforcement hypotheses in Phaseolus vulgaris? Physiol. Plant., doi: 10.1111/ppl.12895.

Mwadzingeni, L., H. Shimelis, E. Dube, M.D. Laing, and T.J. Tsilo. 2016. Breeding wheat for drought tolerance: Progress and technologies. J. Integr. Agr. 15:935-943.

Mohamed, S.A. and H. Ibrahim. 2011. Alleviation of adverse effects of drought stress on common bean (Phaseolus vulgaris L.) by exogenous application of hydrogen peroxide. Bangl. J. Bot. 40:75-83.

Moura, D.S., G.G. de Brito, Í.L. Moraes, P.R.R Fagundes, A.P. Castro, and S. Dauner. 2018. Cold tolerance in rice plants: phenotyping procedures for physiological breeding. J. Agr. Sci. 10:1-12.

Moussa, H.R. and S.M. Abdel-Aziz. 2008. Comparative response of drought tolerant and drought sensitive maize genotypes to water stress. Austral. J. Crop Sci. 1:31-36.

Ortiz, E., M. Cruz, L.M. Melgarejo, X. Marquínez, and L. Hoyos-Carvajal. 2014. Histopathological features of infections caused by Fusarium oxysporum and $F$. solani in purple passionfruit plants (Passiflora edulis Sims). Summa Phytopathol. 40:134-140.

Osman, H.S. 2015. Enhancing antioxidant-yield relationship of pea plant under drought at different growth stages by exogenously applied glycine betaine and proline. Ann. Agr. Sci. 60:389-402.

Pang, J., N.C. Turner, T. Khan, Y.L. Du, J.L. Xiong, T.D. Colmer, R. Devilla, K. Stefanovaand, and K.H.M. Siddique. 2016. Response of chickpea (Cicer arietinum L.) to terminal drought: Leaf stomatal conductance, pod abscisic acid concentration, and seed set. J. Expt. Bot. 68:1973-1985.

Polania, J., I.M. Rao, C. Cajiao, M. Rivera, B. Raatz, and S. Beebe. 2016. Physiological traits associated with drought resistance in Andean and Mesoamerican genotypes of common bean (Phaseolus vulgaris L.). Euphytica 210:17-29.

Porch, T.G., R. Bernsten, J.C. Rosas, and M. Jahn. 2007. Climate change and the potential economic benefits of heat tolerant bean varieties for farmers in Atlántida, Honduras. J. Agr. Univ. P. R. 91:133-148.

Reynolds, M. and P. Langridge. 2016. Physiological breeding. Curr. Opin. Plant Biol. 31:162171.

Rosales, M.A., E. Ocampo, R. Rodríguez-Valentín, Y. Olvera-Carrillo, J. Acosta-Gallegos, and A.A. Covarrubias. 2012. Physiological analysis of common bean (Phaseolus vulgaris L.) cultivars uncovers characteristics related to terminal drought resistance. Plant Physiol. Biochem. 56:24-34.

Sánchez-Reinoso, A.D., G.A. Ligarreto-Moreno, and H. Restrepo-Díaz. 2018. Physiological and biochemical expressions of a determinated growth common bean genotype (Phaseolus vulgaris L.) to water deficit stress periods. J. Anim. Plant Sci. 28:119-127.

Sánchez-Rodríguez, E., M. Rubio-Wilhelmi, L.M. Cervilla, J.J. Blasco, J.J. Rios, M.A. Rosales, L. Romero, and J.M. Ruiz. 2010. Genotypic differences in some physiological parameters symptomatic for oxidative stress under moderate drought in tomato plants. Plant Sci. 178:3040.

Scoffoni, C., C. Vuong, S. Diep, H. Cochard, and L. Sack. 2014. Leaf shrinkage with dehydration: Coordination with hydraulic vulnerability and drought tolerance. Plant Physiol. 164:17721788 .

Seelig, H.D., R.J. Stoner, and J.C. Linden. 2012. Irrigation control of cowpea plants using the measurement of leaf thickness under greenhouse conditions. Irrig. Sci. 30:247-257.

Soltys-Kalina, D., J. Plich, D. Strzelczyk-Żyta, J. Śliwka, and W. Marczewski. 2016. The effect of drought stress on the leaf relative water content and tuber yield of a half-sib family of 'Katahdin'-derived potato cultivars. Breed. Sci. 66:328-331.

Waqas, M., M.T. Azhar, I.A. Rana, A. Arif, and R.M. Atif. 2019. Drought stress in chickpea: Physiological, breeding, and omics perspectives, p. 189-227. In: S.H. Wani (ed.). Recent approaches in omics for plant resilience to climate change. Springer, Cham, Switzerland.

White, J.W. and S.P. Singh. 1991. Breeding for adaptation to drought, p. 501-560. In: A. van Schoonhoven and O. Voysest (eds.). Common beans, research for crop improvement. $\mathrm{CAB}$ Int., Wallingford, UK.

Winterhalter, L., B. Mistele, S. Jampatong, and U. Schmidhalter. 2011. High throughput phenotyping of canopy water mass and canopy temperature in well-watered and drought stressed tropical maize hybrids in the vegetative stage. Eur. J. Agron. 35:22-32. 